\title{
Assessment of Certain Strategies to Manage Fruit Fly Bactrocera cucurbitae (Coquillett) in Bitter Gourd of Tripura
}

\author{
Ardhendu Chakraborty ", Dipak Nath, Subhra Shil, Dipankar Dey, Rajib Das, \\ Suresh Chandra Biswas, Nurul Islam and Subrata Choudhury
}

Krishi Vigyan Kendra, Khowai, Tripura - 799207, India

*Corresponding author

\section{A B S T R A C T}

Keywords

Fruit fly,

Bactrocera,

management

Article Info

Accepted:

17 June 2019

Available Online:

10 July 2019
Field experiment on the performance of different management strategies against fruit fly, Bactrocera cucurbitae (Coquillett) infesting bitter gourd was carried out during kharif 2017 and 2018 at farmers' field. The results revealed that significantly lowest mean number of ovipositional punctures (1.72 and 1.98/fruit), lowest mean number of maggots (10.00 and 10.93/fruit), lowest mean percent of fruit infestation (13.92 and $16.90 \%$ ) and higher fruit yield (15.73 and 16.59 t/ha.) as well as the highest costbenefit ratio (1: 2.31 and $1: 2.44)$ as compared to the other treatments was recorded in the treatment with the pheromone traps @ 25/ha + gur based poison bait trap $(50 \mathrm{ml}$ Malathion $50 \mathrm{EC}+200 \mathrm{~g}$ gur +2 litre water) during both the year.

\section{Introduction}

Cucurbits, a common name given to a number of vegetable crops belonging to botanical family cucurbitaceae which mostly possess trailing habit, are extensively grown all over the tropical and sub-tropical countries and include the largest number of summer and rainy season vegetables (Bharadiya and Bhut, 2017). Tephritid fruit flies, Bactrocera spp. are the most serious and destructive insect pests infesting all cucurbit vegetables worldwide except in Arctic and Antarctic regions (Kapoor et al., 1980). The extent of loss inflicted by these dipteran flies is varying from 30 to $100 \%$ depending upon cucurbit species and environmental conditions (Shooker et al., 2006).

Their attack not only reduce yield but also affect fruit quality hence farming enterprises rendered unprofitable. In Himachal Pradesh, Bactrocera tau (Walker), B. cucurbitae (Coquillett), B. scutellaris (Bezzi) have been reported as the predominant fruit fly species which cause heavy losses in cucurbit and tomato crops in low and mid hill areas (Prabhakar et al., 2007; Singh et al., 2013).

The melon fruit fly, Bactrocera cucurbitae 
(Coquillett) is a serious pest of cultivated cucurbits. It was first reported in India by Lefroy during 1907 which reduce not only the quality of fruits and vegetables but also a serious limiting factor in the production of gourds, cucumber, melon and other cucurbits to the extent that it's growing may become highly unprofitable. Generally, the female fruit flies puncture the soft and tender fruits by their sharp ovipositor and lay the eggs under fruit tissues and guumy fluid oozes from the puncture. The fruit flies also oviposit in the tender plant tissues such as terminals, unopened flowers, young stems and seedlings which may result in the death of the plant (Kate et al., 2009). After hatching, the maggots feed on the pulp of the fruits by making galleries and simultaneously the secondary infection also arises, resulting in rotting of fruits (Gupta and Verma, 1995).

The extent of losses caused by B. cucurbitae varies from 30 to 100 percent depending on the cucurbit species and season (Dhillon et al., 2005). The control measures are as difficult as in the Tephritidae family of insects. Some weak link in the life history of the pest is exploited by the economic entomologists. Several management techniques are being applied against this pest because three of its life stages are hidden and the only adult stage is the usual target for its management. Mostly chemically-based insecticides are used for their control without knowing the ill effects of these chemicals on the environment. The residues of pesticide affected the export potential of gourd because of serious concern of the importing countries (Quasem, 2003). Moreover, repeated use of toxic insecticides is not only hazardous to the environment but also directly affects the health of the farmers and consumers. Therefore, it is necessary to explore economically sustainable and environment-friendly insecticides for management of fruit fly.

Keeping in mind the aforesaid hazardous impact of chemicals on the environment, human's health and economic importance of this pest, the present investigation was undertaken to assess the performance of certain management strategies to control fruit fly in bitter gourd.

\section{Materials and Methods}

With a view to find out the performance of different strategies for control of fruit fly in bitter gourd, field experiments were conducted in randomized block design with 8 replications at farmers' field under KVK Khowai during two consecutive year kharif 2017 and 2018. All the recommended agronomical practices were followed to raise good crop. The insecticidal solutions were sprayed through manually operated hydraulic knapsack sprayer till the whole plant was cover thoroughly. The treatments included T1: Farmers usual practices i.e. 5 - 6 times spray of Malathion 50 EC@2.0 m1/lit., T2: Azadirachtin 300 ppm @ $5.0 \mathrm{ml} / \mathrm{lit} ., \mathrm{T} 3:$ Pheromone traps @ $25 /$ ha + gur based poison bait trap $(50 \mathrm{ml}$ Malathion $50 \mathrm{EC}+200 \mathrm{~g}$ gur +2 litre water) and T4: control.

A total of two foliar spray applications were taken at 15 days interval in T2 and T3. The treatments for the management of fruit fly were imposed at 5th and 8th week after sowing by using Knapsack sprayer after taking the pre-treatment count of fruit fly damage. The first foliar spray was taken at the fruit setting stage when oviposition marks were noticed on bitter gourd fruits and when the fruit flies caught in the pheromone trap crossed the economic threshold level of 1.46 adults per trap per day. From each treatment, five plants were selected (randomly) and the observations on the number of ovipositional punctures per fruit, number of maggots per fruit and percent fruit infestation due to fruit fly before treatment and three, five and ten days after treatment was recorded. Percent 
fruit damage was worked out by using formula

Per cent fruit damage $=\frac{\text { Number of fruits infested }}{\text { Total number of fruits observed }} \times 100$

Furthermore, five infested fruits from each treatment were randomly selected, plucked and brought to the laboratory to count the number of maggots. These infested fruits were cut open near the damaged part of the fruit and the numbers of maggots in the pulp of the infested fruit were recorded. In each plot, irrespective of healthy and infested, marketable sized bitter gourd fruits were harvested. At each fruit picking, the healthy and infested fruits were sorted out separately, weighed and noted. The weight of the healthy fruits from all the fruit pickings in each plot was pooled to get yield per plot $(\mathrm{kg})$ and was converted to yield per hectare (tonnes). Further, the Cost-Benefit ratio (C: B ratio) was also worked out to determine the best treatment. The data about performance trial were analyzed using one way ANOVA. The mean values for all the parameters were calculated and the analysis of variance was accomplished and means were separated by Duncan's Multiple Range Test (DMRT) (Srinivas et al., 2018).

\section{Results and Discussion}

The results of the present investigation on the assessment of certain strategies to manage fruit fly Bactrocera cucurbitae (Coquillett) in bitter gourd crop exhibited variable performance in reducing the number of ovipositional punctures, number of maggots as well as a fruit infestation over untreated control during kharif 2017 and 2018 (Table 1) (Figure 1). The data revealed that the treatment T3 was found significantly more effective in reducing the fruit fly infestation during both the years. The treatment, T3 recorded significantly lowest mean number of ovipositional punctures (1.72 and 1.98/fruit), lowest mean number of maggots (10.00 and 10.93/fruit), lowest mean percent of fruit infestation (13.92 and $16.90 \%)$ and fetched significantly higher fruit yield (15.73 and $16.59 \mathrm{t} / \mathrm{ha}$.) as well as the highest cost-benefit ratio (1: 2.31 and $1: 2.44)$ as compared to the other treatments during kharif 2017 and 2018, respectively (Table 1). The treatment $\mathrm{T} 3$ was statistically on par with $\mathrm{T} 1$ in which 2.38 and 2.41 mean number of ovipositional punctures, 13.28 and 12.94 mean number of maggots per fruit, 24.28 and 28.57 mean percent of fruit infestation, 11.58 and 10.72 tonnes/ ha. of fruit yield with a cost-benefit ratio of 1: 1.73 and 1: 1. 60 was recorded during kharif and summer season respectively. The results were in agreement with results of Sawai et al., (2014) who reported that the treatment DDVP (dichlorvos) was also found better in managing the fruit fly in ridge gourd after the treatment deltamethrin with lowest fruit damage $(22.83 \%)$, highest marketable yield (19.96 t/ha.) and highest incremental benefitcost ratio (1: 26.51). Further, T2 was the next better strategy against fruit fly as it recorded 2.32 and 2.33 mean number of ovipositional punctures, 12.73 and 12.42 mean number of maggots, 22.05and 25.84 mean percent fruit infestation, 12.38 and 12.27 tonnes/ha. of fruit with a cost-benefit ratio of 1: 1.81 and 1: 1.79 during both the year, respectively. These results are in accordance with the results obtained by Ranganath et al., (1997) who recorded higher yield from Azadirachtin 1 per cent EC over neem soap in cucumber. Similarly, Sharma et al., (2016) recorded higher yield from Nimbicidine over other botanicals in organically grown cucumber. Khursheed and Desaraj (2012) reported that spraying of Azadirachtin 1 per cent EC was superior to Malathion for controlling melon fruit fly with less percent fruit damage of 16.66 per cent as against 28.89 per cent in Malathion in cucumber. 
Table.1 Assessment of certain management strategies against fruit fly, Bactrocera cucurbitae in bittegourd

\begin{tabular}{|c|c|c|c|c|c|c|c|c|c|c|c|}
\hline \multirow[t]{2}{*}{$\begin{array}{l}\text { Trt. } \\
\text { No. }\end{array}$} & \multirow[t]{2}{*}{ Treatments } & \multicolumn{2}{|c|}{$\begin{array}{c}\text { Mean no. of } \\
\text { ovipositional } \\
\text { punctures /fruit* }\end{array}$} & \multicolumn{2}{|c|}{$\begin{array}{c}\text { Mean no. of } \\
\text { maggots /fruit* }\end{array}$} & \multicolumn{2}{|c|}{$\begin{array}{l}\text { Mean \% fruit } \\
\text { infestation** }\end{array}$} & \multicolumn{2}{|c|}{ Yield (t/ha.) } & \multicolumn{2}{|c|}{ C: B ratio } \\
\hline & & 2017 & 2018 & 2017 & 2018 & 2017 & 2018 & 2017 & 2018 & 2017 & 2018 \\
\hline T1 & $\begin{array}{l}\text { Farmers usual } \\
\text { practices i.e. } 5-6 \\
\text { times spray of } \\
\text { Malathion } 50 \text { EC @ } \\
2.0 \mathrm{ml} / \mathrm{lit} .\end{array}$ & $\begin{array}{l}2.38 \\
(1.37) b\end{array}$ & $\begin{array}{l}2.41 \\
(1.38) b c\end{array}$ & $\begin{array}{l}13.28 \\
(3.43) b\end{array}$ & $\begin{array}{l}12.94 \\
(3.38) c\end{array}$ & $\begin{array}{l}24.28 \\
(30.13) b c\end{array}$ & $\begin{array}{l}28.57 \\
(32.90) \mathrm{c}\end{array}$ & 11.58 & 10.72 & 1.73 & 1.60 \\
\hline $\mathbf{T} 2$ & $\begin{array}{l}\text { Azadirachtin } 300 \text { ppm } \\
\text { @ } 5.0 \mathrm{ml} / \mathrm{lit} .\end{array}$ & $\begin{array}{l}2.32 \\
(1.35) \mathrm{cd}\end{array}$ & $\begin{array}{l}2.33 \\
(1.35) b c\end{array}$ & $\begin{array}{l}12.73 \\
(3.35) \mathrm{cde}\end{array}$ & $\begin{array}{l}12.42 \\
(3.30) \mathrm{bc}\end{array}$ & $\begin{array}{l}22.05 \\
(28.66) \mathrm{cd}\end{array}$ & $\begin{array}{l}25.84 \\
(31.18) \mathrm{c}\end{array}$ & 12.38 & 12.27 & 1.81 & 1.79 \\
\hline T3 & $\begin{array}{l}\text { Pheromone traps @ } \\
25 / \text { ha + gur based } \\
\text { poison bait trap }(50 \mathrm{ml} \\
\text { Malathion } \\
50 \mathrm{EC}+200 \mathrm{~g} \text { gur }+2 \\
\text { litre water) }\end{array}$ & $\begin{array}{l}1.72 \\
(1.10) \mathrm{a}\end{array}$ & $\begin{array}{l}1.98 \\
(1.21) \mathrm{a}\end{array}$ & $\begin{array}{l}10.00 \\
(2.92) a\end{array}$ & $\begin{array}{l}10.93 \\
(3.07) \mathrm{a}\end{array}$ & $\begin{array}{l}13.92 \\
(22.71) a\end{array}$ & $\begin{array}{l}16.90 \\
(25.03) \mathrm{a}\end{array}$ & 15.73 & 16.59 & 2.31 & 2.44 \\
\hline T4 & Control & $\begin{array}{l}3.57 \\
(1.75) \mathrm{e}\end{array}$ & $\begin{array}{l}3.59 \\
(1.76) \mathrm{c}\end{array}$ & $\begin{array}{l}19.66 \\
(4.26) f\end{array}$ & $\begin{array}{l}20.34 \\
(4.34) \mathrm{d}\end{array}$ & $\begin{array}{l}42.98 \\
(41.50) \mathrm{e}\end{array}$ & $\begin{array}{l}53.05 \\
(47.29) d\end{array}$ & 10.10 & 9.20 & 1.68 & 1.40 \\
\hline & $\mathrm{CD}$ & 0.25 & 0.30 & 0.52 & 1.56 & 9.10 & 12.77 & - & - & - & - \\
\hline
\end{tabular}

*Figures in the parentheses are square root transformed values, **Figures in the parentheses are angular transformed values 
Fig.1 Performance trend of management strategies against fruit fly

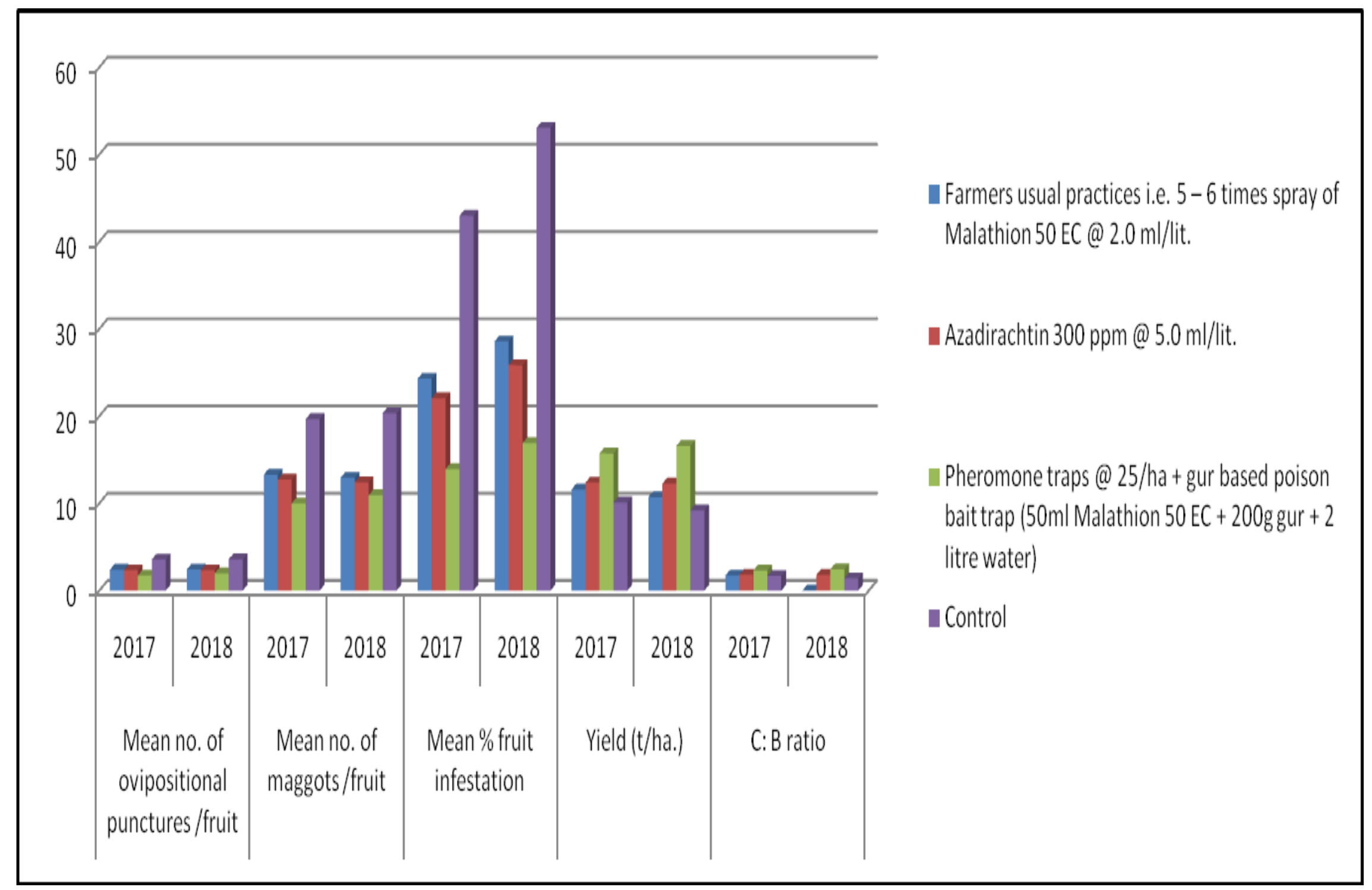


Similarly, Waseem et al., (2009) reported the lowest fruit damage of 7.33 per cent due to neem product (nimbex $0.15 \%$ ) as against untreated check damage $(54.33 \%)$ in cucumber against melon fruit fly. The present results partly conform with Oke (2008) who observed that deltamethrin and lambdacyhalothrin were effective against $B$. cucurbitae on cucumber. Further, the highest number of ovipositional punctures (3.57 and 3.59/fruit), highest number of maggots (19.66 and 20.34/fruit), highest percent of fruit infestation (42.98 and $53.05 \%$ ), lowest yield (10.10 and $9.20 \mathrm{t} / \mathrm{ha}$.) and lowest cost-benefit ratio (1: 1.68 and 1: 1.40) was recorded in control. Minimum infestation in T3 as because, gur acts as a phagostimulant, which induces sustained feeding and attract pests resulting in more trapped insects. Most dipterans, especially adult tephritids, for their survival and reproduction they actively search for food sources such as honeydew, nectar, plant juice, bacteria, yeast and animal excreta (Prokopy and Roitberg, 1992). Hence, the order of management strategies against melon fruit fly is Pheromone traps @ 25/ha + gur based poison bait trap $(50 \mathrm{ml}$ Malathion $50 \mathrm{EC}$ $+200 \mathrm{~g}$ gur +2 litre water) $>$ Farmers usual practices i.e. $5-6$ times spray of Malathion 50 EC @ 2.0 ml/lit. > Azadirachtin 300 ppm @ $5.0 \mathrm{ml} / \mathrm{lit}$.

\section{References}

Bharadiya AM and Bhut JB. 2017. Effect of different insecticides against fruit fly, Bactrocera cucurbitae Coquillett infesting sponge gourd. International Journal of Chemical Studies 2017; 5(5): 1866-1868.

Dhillon MK, Naresh JS, Singh R, Sharma NK. Evaluation of bitter gourd (Momordica charantia L.) genotypes for resistance to melon fruit fly (Bactrocera cucurbitae). Indian Journal of Plant Protection. 2005; 33(1): 55-59.
Gupta BL, Verma AK. Host-specific demographic studies of the melon fruit fly, Dacus cucurbitae Coquillett (Diptera: Tephritidae). Journal of Insect Sciences. 1995; 89(1): 87-89.

Kapoor, V.C., Hardy, D.E., Aggarwal, M.L. and Grewal, J.S. 1980. Fruit fly (Diptera: Tephritidae), systematics of Indian Subcontinent, Export Indian Publishers, Jalandhar, Punjab, 113 P.

Kate AO, Bharodi RK, Joshi MD, Pardeshi AM, Makadia RR. Seasonal incidence of fruit fly, Bactrocera cucurbitae (Coquillet) on cucumber. Asian sciences 2009; 4(2): 83-84.

Khursheed S, Deshraj. Bio-efficacy of certain insecticides and biopesticides against melon fruit flies, Bactrocera spp. Pest Management in Horticulture Ecosystem. 2012; 18(2): 143-148.

Oke OA. Effectiveness of two insecticides to control melon fruit fly (Bactrocera cucurbitae (Coquillet) in cucumber (Cucumis sativus L). crop at Anse Boileau Seychelles. European Journal of Science and Research.

Prabhakar, C.S., Sood, P., Mehta, P.K. and Chaudhary, A. 2007. Fruit fly, Bacterocera scutellaris (Bezzi): a potential threat to cucurbit cultivation under low and mid hills of Himachal Pradesh. Pest Management and Economic Zoology, 15(2): 181-185.

Prokopy RJ, Roitberg BD. Fruit fly foraging behaviour. In (Edited by Robinson A $\mathrm{S}$ and Hooper G). Fruit flies; their biology, natural enemies and control. Elsevier, Amsterdam, 1992, 293-306.

Quasem MA. Export of fresh horticultural crops from Bangladesh: Problems and prospects. A first draft report presented at BARC, on 21 August, 2003, 65.

Ranganath HR, Suryanarayana MA, Veenakumari K. Management of melon fly (Bactrocera (Zeugodacus) cucurbitae) in cucurbits in South 
Andaman. Insect Environment. 1997; 3(3): 32-33.

Sharma SK, Punam, Kumar R. Management of fruit fly (Bactrocera spp.) in cucumber (Cucumis sativus Linn.) grown organically. Journal of Biopesticides. 2016; 9(1):73-79.

Shooker, P., Khayrattee, F. and Permalloo, S. 2006. Use of maize as a trap crops for the control of melon fly, B. cucurbitae (Diptera: Tephritidae) with GF-120. Bio-control and other control methods (online). Available on: httpllwww.fcla. edu/flaEnt/fe87 p354. Pdf.

Singh, M., Gupta, D. and Sharma, D. 2013. Bactrocera scutellaris (Bezzi) - a dominant fruit fly species in vegetable fields in mid hills of Himachal Pradesh. Insect Environment, 19(3): 137-139.

Srinivas MP, Suchithra Kumari MH, Hanumantharaya L, Thippeshappa GN and Yalleshkumar HS. Bio-efficacy of insecticides against fruit fly, Bactrocera cucurbitae (Coquillett) in cucumber. Journal of Entomology and Zoology Studies 2018; 6(6): 449-45.

Waseem MA, Nagangoud A, Patil BV, Prabhuraj A, Hussain A. Efficacy of some insecticides against melon fly, Bactrocera cucurbitae (Coq.) on cucumber. Karnataka Journal of Agriculture Science. 2009. 22(3): 701702.

\section{How to cite this article:}

Ardhendu Chakraborty, Dipak Nath, Subhra Shil, Dipankar Dey, Rajib Das, Suresh Chandra Biswas, Nurul Islam and Subrata Choudhury. 2019. Assessment of Certain Strategies to Manage Fruit Fly Bactrocera cucurbitae (Coquillett) in Bitter Gourd of Tripura. Int.J.Curr.Microbiol.App.Sci. 8(07): 2386-2392. doi: https://doi.org/10.20546/ijcmas.2019.807.292 